\title{
Effects of in-feed enzymes on milk production and components, reproduction, and health in dairy cows
}

\author{
H. M. Golder, ${ }^{1}$ H. A. Rossow, ${ }^{2}$ and I. J. Lean ${ }^{1 *}$ \\ ${ }^{1}$ Scibus, Camden, NSW 2570, Australia \\ ${ }^{2}$ Veterinary Medical Teaching and Research Center, University of California, Davis 93274
}

\begin{abstract}
Our objectives were to characterize responses in the field to a mix of fibrolytic enzymes using large commercial dairy herds and sufficient study power to evaluate milk production and reproductive responses to an enzyme treatment started during the precalving period. We hypothesized that the use of the enzyme treatment would increase milk production when provided to dairy cows precalving and for approximately $200 \mathrm{~d}$ of lactation. The study was conducted on 7,507 cows, in 8 replicates and 16 pens, at 3 dairies in the United States. Eight pens were randomly allocated as control pens and received no enzyme, and another 8 pens received enzyme treatment at a dose of $750 \mathrm{~mL} / \mathrm{t}$ of dry matter feed. Milk production and energy-corrected milk yield were increased with the enzyme treatment by 0.70 and $0.80 \mathrm{~kg} / \mathrm{d}$, respectively, across a 5 -month period. Milk fat percentage was not significantly increased by enzyme treatment, but milk fat yield was significantly increased by $0.040 \mathrm{~kg} / \mathrm{d}$, compared with controls. Milk protein yield increased $0.010 \mathrm{~kg} / \mathrm{d}$ with enzyme treatment despite a small reduction of 0.020 percentage units in milk protein percentage. We found no evidence of an increase in the ln somatic cell count for the enzymetreated cows. Body weight overall was not increased for enzyme-treated cows, but we did observe a numerical increase in dry matter intake $(0.20 \mathrm{~kg} /$ head per day $)$ for enzyme-treated cows. Most production responses to the enzyme treatment were influenced by dairy. Compared with controls, milk yield in enzyme-treated cows was significantly higher by $3.6 \mathrm{~kg} / \mathrm{d}$ in dairy 2 and numerically higher by 0.60 and $0.20 \mathrm{~kg} / \mathrm{d}$ in dairies 1 and 3, respectively. Reproduction, health, and risk of removal or death were not significantly influenced by treatment, apart from a reduced time to first breeding. Production responses to the enzyme treatment varied by dairy from substantial to minor increases, but varia-
\end{abstract}

Received March 12, 2019.

Accepted May 6, 2019

*Corresponding author: ianl@scibus.com.au tion among dairies was not evident in differences in dry matter intake or in partitioning of body weight among enzyme-treated and control pens and cows. It appears likely that the increase in production reflected increased digestibility of feed; however, further work is needed to identify factors influencing the variation in production responses to enzymes.

Key words: fibrolytic enzyme, milk production, reproduction

\section{INTRODUCTION}

The specific mix of fibrolytic enzymes applied in this study has been used to increase milk production, as demonstrated in individual studies (Rode et al., 1999; Yang et al., 1999, 2000) and as one of several enzyme products evaluated in meta-analyses (Arriola et al., 2017; Tirado-González et al., 2018). The latter studies indicated that the use of enzymes increased milk and milk protein production. The intervention has been effective in increasing milk and milk solids production, but results are variable, as indicated by significant heterogeneity of responses in the study of Arriola et al. (2017).

Factors that influence responses to enzyme treatment are not well characterized. Inconsistent milk production responses to fibrolytic enzymes, in general, have been attributed to differences in enzyme activity, application rate and composition, dairy cow stage of lactation, mode and time of enzyme delivery, ruminal microbial activity, ruminal enzyme stability, enzyme-feed specificity, and the portion of the diet to which enzymes are applied (Beauchemin et al., 2004; Adesogan, 2005). Additional factors that may explain the variability include insufficient statistical power, inappropriate experimental designs and or durations, inappropriate enzyme choices, and use of inappropriate measures of enzyme activity and misleading enzyme designations (Arriola et al., 2017). Finally, the physical form of application of enzymes may also be an important consideration in understanding variability; moisture may be required to provide effective distribution to sites of action. 
The objectives of this study were to characterize responses in the field to a specific mix of fibrolytic enzymes in commercial dairy herds with sufficient study power to evaluate the milk production and reproductive responses to the enzyme treatment that commenced during the precalving period. The hypothesis was that the use of the enzyme treatment would increase milk production when provided to cows precalving and for approximately $200 \mathrm{~d}$ of lactation. A strong secondary interest was to evaluate the effects of the enzyme on reproductive performance.

\section{MATERIALS AND METHODS}

This study was approved by the University of California, Davis, Animal Care and Use Committee.

\section{Dairy Selection Criteria}

We selected 3 dairies that provided a total of 8 replicates with 16 pens ( 8 enzyme and 8 control) for use in the study, because they had good record keeping and a history of performance that suggested they would be capable of maintaining attention to detail consistent with successful study conduct. Specifically, the dairies met the following criteria: an ability to record daily milk and milk solids production on a regular basis; information available on the cows used in the study to provide clear identification, parity, and pregnancy status; an ability to ensure that feeding was conducted accurately and weights of feed offered and orts could be measured; cows weighed daily or more often; a monitor present to assist with protocol compliance; and pens used were as identical as possible, with a minimum of 2 per dairy. If necessary, a pen rotation was used to establish different replicates and ensure similarity of environmental exposure for pens. Further selection criteria included that records were easily retrieved and could be validated to evaluate anomalies in data; and the herds were willing to comply with a 150-d study minimum to allow an evaluation of reproduction data.

Dairy 1 provided 2 replicates, was located in the Hamlin County, South Dakota, and was positively ventilated with freely available drinking water. Dairy 2 was in Tulare County, California, and also provided 2 replicates. Dairy 3 was in Kerman, California, and provided 4 replicates; the California dairies were freestall sheds with fans and wetters in loafing areas, and drinking water was freely available. We considered that a geographical spread of the dairies would help to improve the external validity of the study. The study was conducted from December 2015 to January 2018. Standard operating procedures were developed to describe the methods of enzyme application, recording of health and reproductive data, and feeding methods for the dairies. Diagnosis of disease was done primarily by dairy staff.

\section{Treatment Pen Allocation}

Pens used in the study were randomly assigned to control or enzyme treatments; parity 1 and older pens were allocated separately by the toss of a coin. All cows in the dry pens $(8,173$ cows) with a projected calving date entered the study and were allocated systematically based on odd and even ear tags that were randomly assigned by the toss of a coin to control or enzyme treatment. We considered blinding of treatments but rejected it because it was important to minimize the risk of error in treatment allocation during feed mixing. Finally, groups were identified based on differences in an additional colored ear button and as having odd- or even-numbered ear tags.

\section{Sample Size Determinations}

The power calculations for the study were based on the milk production responses observed in an enzyme meta-analysis by I. J. Lean et al. (unpublished data) and used the rdpower program in Stata version 14.1 (StataCorp LP, College Station, TX), appropriate for determining sample sizes for a 2-level cluster study design. We assumed that the effect size response would be 1 standard deviation greater than the control. This response was consistent with but lower than milk responses observed in an unpublished meta-analysis of responses for the enzyme treatment (I. J. Lean et al., unpublished data). The intra-class correlation was also evaluated between 0.1 and 0.2 . For 6 replicates per treatment with pens of 400 cows, an effect size of 0.6 , and intra-class correlation of 0.1 , the study power was 0.83 . More pens and cows were enrolled to allow for assessment of the reproductive and health responses that were of secondary interest.

\section{Study Treatment}

All treated pens were exposed to a specific mix of fibrolytic enzymes (AB Vista, Marlborough, UK), in a liquid pre-treatment. The enzyme mix is a fermentation product of Trichoderma reesei and contains declared minimum activities of $350,000 \mathrm{BXU} / \mathrm{g}$ of xylanase (EC 3.2.1.8) and 10,000 ECU/g of cellulase (EC 3.2.1.4), where $1 \mathrm{BXU}$ is the amount of enzyme that will release $0.06 \mu \mathrm{mol}$ of reducing sugars (xylose equivalents) from birch xylan per minute at $\mathrm{pH} 5.3$ and $50^{\circ} \mathrm{C}$; and $1 \mathrm{ECU}$ is the amount of enzyme that will release $0.06 \mu \mathrm{mol}$ of 
reducing sugars as glucose from hydroxyethyl cellulose per minute at $\mathrm{pH} 4.8$ and $50^{\circ} \mathrm{C}$.

Pens and cows were administered the enzyme treatment on a DMI basis, as per label directions, at a rate of $750 \mathrm{~mL} / \mathrm{t} \mathrm{DM}$ of feed. The enzyme was mixed with water and administered directly onto the TMR in mixer wagons. To validate the amount of enzyme being used, we undertook a weekly enzyme reconciliation to ensure that the volume of enzyme used was consistent with the anticipated rate of use. Xylanase and cellulase activity were measured using wet chemistry by Enzyme Services and Consultancy, Innovation and Technology Centre (Ystrad Mynach, UK) to identify the presence of active enzymes in TMR samples. Xylanase activity (EC 3.2.1.8) was analyzed using xylazyme AX $60 \mathrm{mg}$ tablets (Megazyme T-XAX200; Megazyme International Ireland Ltd., Bray, Wicklow, Ireland) as a substrate. Cellulase activity (EC 3.2.1.4) was analyzed using Cellazyme-C tablets (Megazyme International Ireland Ltd.) as a substrate. Cows received enzyme-treated feed or control feed for a minimum of $150 \mathrm{~d}$ in lactating cow strings and for variable periods before calving.

\section{Feeding and Feed Analysis}

Ration samples were collected for each differently formulated TMR - usually precalving, fresh, and highyield strings - once a week for nutrient analyses. In short, 3 empty feed tubs were placed in feed bunks just before the mixer wagon delivered a load. Tubs (approximately 8-10 kg as-fed TMR per tub) were then collected and the contents mixed on a large clean cement floor. The TMR pile was then quartered, and opposite quarters were mixed and collected into quart-sized zippered plastic bags for nutrient analyses. Samples were frozen at $-20^{\circ} \mathrm{C}$ before submission for laboratory analysis. Details of the TMR fed precalving and during lactation are provided in Tables 1 and 2, respectively.

For dairies 1 and 3, nutrient analysis of the TMR samples was performed at Dairy One Cooperative Inc., Forage Testing Laboratory (Ithaca, NY) according to wet chemistry AOAC International (1999) methods as follows, unless otherwise stated: DM (method 930.15); amylase and sodium sulfite treated NDF (aNDF; Ankom Technology method 6 with solutions from Van Soest et al., 1991); aNDF on an organic matter (ash-free) basis (aNDFom; aNDF with the addition of an ashing step to remove inorganic materials such as minerals, soil, and sand by burning the fibrous residue at $550^{\circ} \mathrm{C}$ for $2 \mathrm{~h}$ with solutions from Van Soest et al., 1991); CP (method 990.03); soluble protein (Cornell sodium borate-sodium phosphate buffer procedure); adjusted $\mathrm{CP}$ (adjusted $\mathrm{CP}=\mathrm{CP}-$ unavailable protein $+1 \%$ ); crude fat by ether extraction (method 2003.05); ash (method 942.05); lignin (Ankom Technology method 9 for acid detergent lignin with solutions from method 973.18): ADF (Ankom Technology method 5 with solutions from method 973.18); acid detergent insoluble CP (ADF residue analyzed using a Leco TruMac N Macro Determinator; Leco Corp., St. Joseph, MI); neutral detergent insoluble CP (Leco TruMac N Macro Determinator); ethanol-soluble carbohydrates (simple sugars; Hall et al., 1999); and starch (YSI 2700 Select Biochemistry Analyzer; YSI Inc., Yellow Springs, OH). The NFC was calculated as NFC $=100-(\mathrm{NDF}+\mathrm{CP}+$ crude fat + ash). The TDN was based on Weiss (1993). The estimated $\mathrm{NE}_{\mathrm{L}}$ was based on NRC (1988). The minerals, with the exception of $\mathrm{Cl}$, were analyzed using a Thermo iCAP 6300 inductively coupled plasma radial spectrometer (Thermo Fisher Scientific Inc., Waltham, $\mathrm{MA}$ ). The $\mathrm{Cl}$ ion was analyzed using a Brinkmann Metrohm 716 Titrino titration unit (Riverview, FL).

Analyses for dairy 2 were performed at Analab (Fulton, IL) by wet chemistry according to AOAC International (1999) methods as follows: absolute DM (method 935.29); CP (method 990.03); aNDF (method 2002.04 using $\alpha$-amylase and sodium sulfite); ADF (method 973.18); soluble protein (Krishnamoorthy et al., 1982); neutral detergent insoluble CP (method 2002.04 without sodium sulfite and method 976.06); acid detergent insoluble CP (methods 973.18 and 976.06); crude fat by ether extraction (method 920.39 with pentane instead of ether); ash (method 942.05); lignin (acid detergent lignin; method 973.18); starch (Smartchem 170 and Smartchem 200 discrete wet chemistry analyzer method GLU-001-A; Unity Scientific, Brookfield, CT); Ca, P, Mg, K, Na, Fe, Zn, Cu, Mn (method 985.01 by inductively coupled plasma spectroscopy); S (method 923.01); and $\mathrm{Cl}$ (method 915.01). Simple sugars were measured using near-infrared spectrometry validated equations based on high-performance anion exchange chromatography using pulse anomeric detection (Metrohm, Herisau, Switzerland) of sample extracts that were calibrated using Sigma-Aldrich (St. Louis, MO) standards. The NFC was calculated as $\mathrm{NFC}=100-$ $[(\mathrm{NDF}-\mathrm{NDICP})+\mathrm{CP}+$ ash $+($ crude fat -1$)]$, where NDICP is neutral detergent insoluble CP. The TDN was based on Van der Honing and Steg (1990). The estimated $\mathrm{NE}_{\mathrm{L}}$ was based on NRC (1988). Feed nutrient analysis results are provided in Table 3.

\section{DMI Determination}

The DMI was estimated from daily group feed delivery weights from the mixer wagon and recorded using the Feed Supervisor feed management software (Super- 
Table 1. Precalving and high-yield lactation diets by dairy

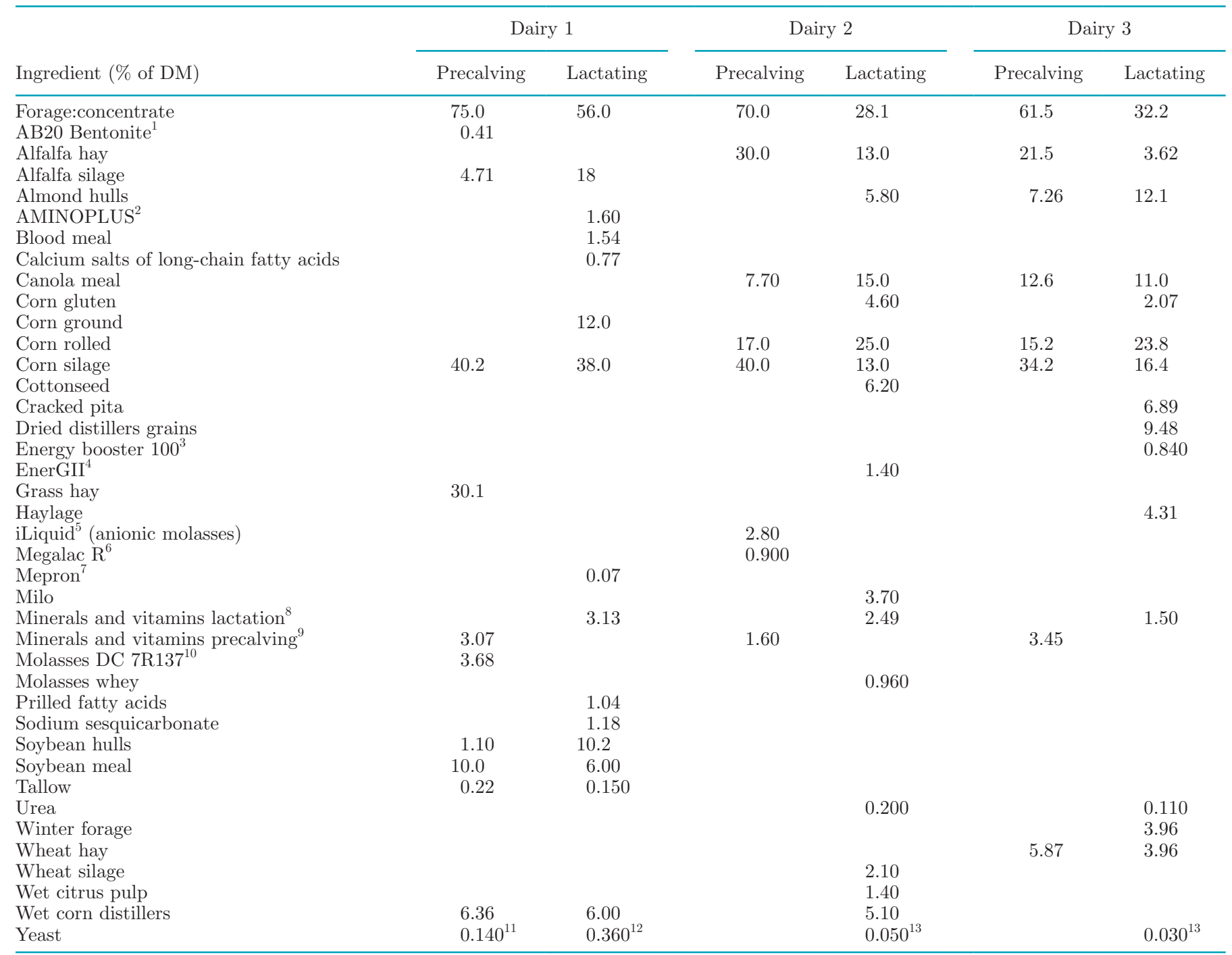

${ }^{1}$ Phibro Animal Health Corp., Teaneck, NJ.

${ }^{2}$ AGP Ag Processing Inc., Omaha, NE.

${ }^{3}$ Milk Specialties Global Animal Nutrition, Eden Prairie, MN.

${ }^{4}$ Virtis Nutrition LLC, Corcoran, CA.

${ }^{5}$ Innovative Liquids, El Dorado Hills, CA.

${ }^{6}$ Arm and Hammer Animal Nutrition, Princeton, NJ.

${ }^{7}$ Evonik Corp., Kennesaw, GA.

${ }^{8}$ Includes sources for $\mathrm{Ca}, \mathrm{P}, \mathrm{Mg}, \mathrm{K}, \mathrm{Na}, \mathrm{Cl}, \mathrm{Mn}, \mathrm{Zn}, \mathrm{Cu}, \mathrm{I}$, Co, Se, vitamin A, vitamin D, vitamin E to meet NRC (2001) requirements. Dairy 1 contains Rumensin 90 (Elanco, Greenfield, IN) at $200 \mathrm{mg} /$ head per day and dairy 3 at $450.4 \mathrm{mg} / \mathrm{head}$ per day.

${ }^{9}$ Includes sources for Ca, P, Mg, K, Na, Cl, Mn, Zn, Cu, I, Co, Se, vitamin A, vitamin D, vitamin E to meet NRC (2001) requirements. Dairy 2 contains Rumensin 90 (Elanco) at approximately $140 \mathrm{mg} /$ head per day and dairy 3 at $217.68 \mathrm{mg} / \mathrm{head}$ per day.

${ }^{10}$ Quality Liquid Feeds LLC, Dodgeville, WI. Contains Rumensin (Elanco) at approximately $300 \mathrm{mg} / \mathrm{head}$ per day.

${ }^{11}$ Integral A+ (Alltech, Nicholasville, KY).

${ }^{12}$ Cel-Con (Western Yeast Co., Chillicothe, IL), Omnigen AF (Phibro Animal Health Corp.), Integral A+ (Alltech), and Procreatin 7 (Lesaffre, Marcq-en-Barœul, France).

${ }^{13}$ Diamond V XPC (Diamond V, Cedar Rapids, IA).

visor Systems, KS Dairy Consulting Inc., Dresser, WI) for dairy 1 and EZFeed (DHI-Provo, Provo, UT) for dairies 2 and 3. All 3 dairies corrected feed delivered with residual feed. Dry matter intakes were on a perpen basis and corrected for residual feed. Then, total corrected DMI was divided by the number of cows in 


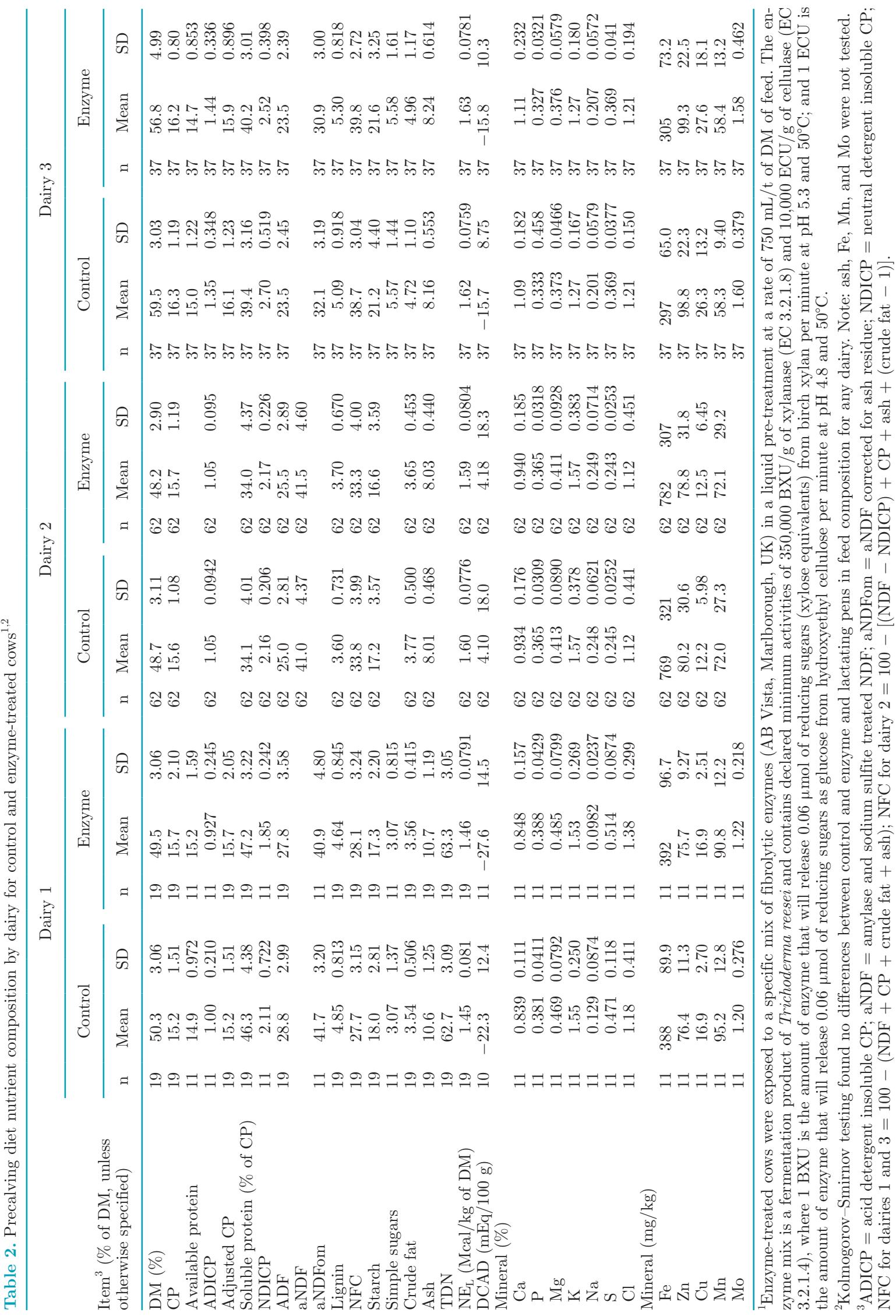




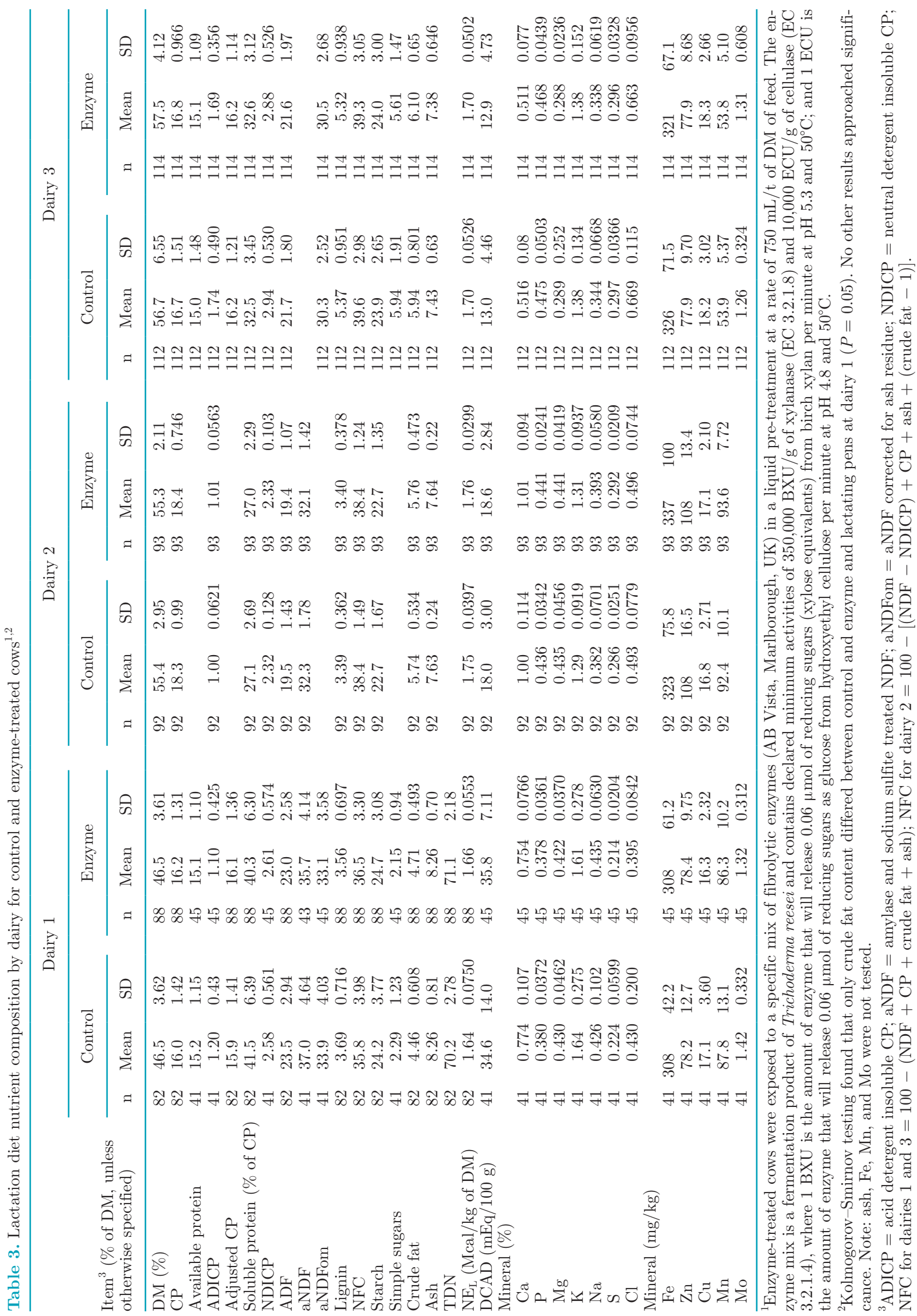


Table 4. Number of cows excluded from the study from each dairy after enrollment by reason

\begin{tabular}{lrrrr}
\hline & \multicolumn{3}{c}{ Dairy } & \\
\cline { 2 - 4 } Reason for exclusion & \multicolumn{1}{c}{ Tryal } \\
\hline Aborted & 1 & 30 & \multicolumn{1}{c}{3} & 37 \\
Calved before start & 86 & 0 & 94 & 180 \\
Calved within 2 wk of end of study & 0 & 7 & 0 & 7 \\
Cow unknown & 0 & 0 & 54 & 54 \\
Data did not make sense & 10 & 4 & 0 & 14 \\
Died before calving & 0 & 5 & 13 & 18 \\
Open & 1 & & 20 & 21 \\
Sold before calving & 0 & 13 & 1 & 14 \\
Unknown exclusion & 1 & 1 & 0 & 2 \\
Unknown or no calving date & 27 & 6 & 2 & 35 \\
Wrong study pen after calving & 70 & 70 & 144 & 284 \\
Total & 196 & 136 & 334 & 666 \\
\hline
\end{tabular}

the pen that day to estimate individual cow DMI. If we found differences between estimates of numbers of cows in pens, data were deleted for that week (deleted $\mathrm{n}=3)$.

\section{Cows Excluded from the Study}

Cows were excluded from the study if they calved before enzyme treatments commenced; aborted; were not pregnant; or were sold before calving. Cows that could not be accounted for from the period of enrollment to lactation entry or that were assigned to the wrong pens at calving for more than 3 consecutive wk were also excluded. These exclusions are detailed in Table 4 .

\section{General Censoring}

Cows that died or were culled were terminated from the milk and BW data at the time of death or decision to remove the cow from the herd. These cows were censored from the survival, reproduction, and health data at that point. Cows that spent more than 3 consecutive wk on the wrong treatment, including being in the hospital pen, were terminated from the milk and BW data at the date of their last weekly milk average in the correct treatment. Survival, health, and reproduction data for these cows were censored $21 \mathrm{~d}$ after entry to the wrong treatment.

\section{Milk Production Data}

All dairies milked 3 times per day. Milk fat, milk protein, and SCC were recorded monthly at herd recording tests by the Minnesota (dairy 1), Tulare (dairy 2), and Fresno (dairy 3) DHI organizations.

Daily milk production was recorded using milking equipment from the GEA Group (Düsseldorf, Germany; dairy 1), BouMatic LLC (Madison, WI; dairy 2), and DeLaval (Tumba, Sweden; dairy 3). Pen movements were reported weekly and used to monitor whether cows were in the correct pens or had been transferred to hospital pens.

Milk yield and component data were included in the analyses from cows that had at least 1 herd test and were allocated to the correct pen. Herd test results collected from cows between 0 and 29 DIM were used as herd test 1 , subsequent test results at $30-\mathrm{d}$ intervals were used as tests 2 to 5 . Energy-corrected milk was calculated as $\mathrm{ECM}=[(0.3246 \times$ milk yield $)+(12.86 \times$ fat yield $)+(7.04 \times$ protein yield $)]$, as per NRC $(2001)$.

\section{BW Data}

Body weight was recorded on an XR 3000 scale (TruTest Limited, Auckland, New Zealand; dairy 1) or an XDS5000 scale (Gallagher Group Pty Ltd., Hamilton, New Zealand; dairies 2 and 3). Body weight was recorded at each milking, but at times the scales failed to record because of physical damage or electrical interference. Some cows had faulty transponders or physical or behavioral attributes that reduced the number of $\mathrm{BW}$ measures.

Body weight data were evaluated for implausible results by first excluding weights of more than 1,100 $\mathrm{kg}$ or less than $400 \mathrm{~kg}$, and then by removing weights that varied by $\pm 100 \mathrm{~kg}$ from one weighing to the next from dairy 1 only. Data were then averaged by cow for each month after calving to produce the final data for evaluation. The removal of weights that varied by \pm 100 $\mathrm{kg}$ from dairy 1 produced similar means and standard deviations to fitting a robust regression model after removal of weights of more than $1,100 \mathrm{~kg}$ and using the predicted values derived from this, indicating that the methods used were acceptable. 


\section{Disease and Reproductive Events}

All cows eligible to enter the study contributed data to the health and reproductive records. Disease and reproductive events including date of calving, breeding events, pregnancy results, hormonal treatments, decisions not to breed, disease diagnosis, disease treatment, and culling were recorded daily using the herd management programs DairyComp305 (Valley Agricultural Software, CA; dairies 1 and 2) or DHI-Plus (DHI-Provo; dairy 3), and exported to Excel and Access (Microsoft Corp.) for processing before statistical analysis.

Health data were entered in accordance with standard operating procedures developed with each dairy. These definitions were largely consistent among dairies and were reviewed for consistency with cow card descriptions and treatments applied.

Cows were both right- and left-censored in the study. Cows that died or were culled before calving were excluded from the reproductive data set because there would have been no intention to breed them. Cows that were designated as "do not breed," including cows identified as being positive for Johne's disease, were censored at the date of that decision. Cows that were not pregnant were censored at the time of removal from enzyme or control pens or at study termination, resulting in full censoring or pregnancy for cows in the study. Most cows had a pregnancy confirmation before removal or after movement to the wrong pen (which allowed determination of pregnancy status at the time of removal), but cows that did not have their status confirmed before removal were considered to be not pregnant at the time of removal. The pattern of censoring was evaluated to identify any possible anomalies in these data.

\section{Statistical Analysis}

The unit of interest was the pen in these studies, but the unit of measurement was primarily the cow. Some measures - specifically DMI and diet - were conducted at the pen level.

The feed analysis results were analyzed using a Kolmogorov-Smirnov 2 sample nonparametric test in Stata (version 15.1; StataCorp LLC, College Station, TX) and are provided in Table 3. One DCAD estimate was removed from dairy 1 control pens, because it was an outlier.

Milk data were initially explored for each dairy and evaluated for the normality of distribution of milk production responses (Stata version 15.1; StataCorp LLC). We recognized that cows in later lactations were not highly represented in the data set, and we categorized lactation number into 4 groups; parity or lactation 1 , 2,3 , and $\geq 4$. The following linear mixed model was fitted to the monthly milk production and BW data, because it was consistent with the study design (StPierre, 2007):

$$
\begin{aligned}
Y_{\mathrm{ijk} l m}=\mu+ & \alpha_{\mathrm{i}}+\gamma_{\mathrm{j}}+\theta_{\mathrm{k}}+\delta_{\mathrm{lm}}+\beta \mathrm{X}_{\mathrm{ijklm}}+\omega \alpha \theta \delta \gamma_{\mathrm{ijkl}} \\
& +\mathrm{f}_{\mathrm{j}}+\mathrm{r}_{\mathrm{i}: \mathrm{nj}}+\mathrm{c}_{\mathrm{m}: \mathrm{ijkln}}+\varepsilon_{\mathrm{ijklmn}},
\end{aligned}
$$

where $\mu$ was the overall mean; $\alpha_{i}$ was the fixed effect of treatment ( $\mathrm{i}=$ control or enzyme); $\gamma_{\mathrm{j}}$ was the fixed effect of dairy ( $\mathrm{j}=$ dairies 1 to 3$) ; \theta_{\mathrm{k}}$ was the fixed effect of parity $(\mathrm{k}=$ parity $1,2,3$, or $\geq 4) ; \delta_{\mathrm{lm}}$ was the fixed effect of time ( $1=$ herd test 1 to 5$)$ for cow number $(\mathrm{m}=1$ to 6,705$) ; \beta \mathrm{X}_{\mathrm{ijklm}}$ was the covariate adjustment for time spent in the pre-fresh pens (days on precalving diet); $\omega \alpha \theta \delta \gamma_{\mathrm{ijk} l}$ were the fixed effects of interaction terms, including 2-, 3-, and 4-way interactions of treatment, dairy, parity, and time; $f_{j}$ was the random effect of dairy; $r_{i: n j}$ was the random effect for the ith treatment within the nth replicate and the jth dairy; $\mathrm{c}_{\mathrm{m}: \mathrm{ijk}} \mathrm{kn}$ was the random interaction effect associated with the lth herd test of the mth cow with the kth parity within the ith treatment within the nth replicate and the jth dairy; and $\varepsilon_{\mathrm{ijklmn}}$ was the random error term.

The covariance was unstructured, unless convergence did not occur (milk yield). Marginal means and contrasts were estimated and used to provide estimates of treatment differences. The SCC data were ln-transformed, because these were not normally distributed. Similar approaches were used for DMI, but, enzyme and control pens at the same stage of lactation were the unit of analysis, and these were analyzed using the fixed effects of treatment (enzyme vs. control), dairy (1, 2, or 3), and week, with all 2- and 3- way interactions between them. The data were repeated-measures (week) within experimental units, with the random effects of pen nested within treatment and dairy. The covariance was unstructured. Marginal means and contrasts were estimated and used to provide estimates of treatment differences.

Different time-failure models that accounted for the random effect of identity within treatment, replicate, and dairy were used to assess survival and reproductive outcomes. A comparison of fit for Cox, Exponential, Lognormal, and Weibull models indicated that the Weibull model had the best fit based on Akaike and Bayesian information criteria. These models accounted for the effects of treatment, dairy, and parity and their interactions as fixed, and the random effects of cow identity within treatment, replicate, and dairy. Days on precalving diet was used as a covariate. 
Differences in health data were assessed using logistic regression mixed models that accounted for treatment, dairy, and parity for variables with outcomes that were considered dichotomous, and time-failure models for outcomes that reflected time-failure events and accounted for the random effect of identity in treatment, replicate, and dairy and the interactions of the fixed effects of treatment, parity, and dairy. Days on precalving diet were used as a covariate.

\section{RESULTS}

The study included 3 dairies and 8 replicates, of which 3 replicates were designated parity 1, providing 16 treatment groups in this study. On an intention-totreat basis, $8.9 \%$ of the cows were lost from the study at the time of enrollment. Most of these were because cows in the dry pen were enrolled before treatments were ready to apply, were not pregnant or were being sold, or were in the wrong pen after calving $(3.5 \%$ of all cows; Table 4). Of the 18 cows that died before calving, 10 were in the control group and 8 were in the enzymetreated group. For the health and reproductive data, 7,507 and 7,500 cows were available in the 8 replicates for analysis, respectively.

\section{Diet and Treatment}

The diets used are shown in Table 1 and analyzed in Tables 2 and 3. We observed a strong consistency in the delivery of diets; only crude fat content was 0.25 percentage units higher in lactating enzyme-treated pens at dairy 1. Most tested differences for feed components between the enzyme-treated and control pens had $P>$ 0.700 for all dairies. Diet differences among dairies were not formally examined in this study, but differences in response to changes in the different feed components are evaluated in a companion paper (H. A. Rossow, H. M. Golder, and I. J. Lean, unpublished).

Assays of the feed for xylanase and cellulase activity and daily monitoring of enzyme use showed that all dairies had enzyme applied to the feed; however, all dairies also had minor lapses in application. In some cases, adequate cellulase activity was present, but xylanase was low, possibly reflecting assay failure.

\section{Production and BW}

At herd test, 6,705 cows provided 26,705 observations, except for SCC, which had 493 fewer observations from 6,688 cows. For BW, we had 18,541 readings from 5,828 cows in the 8 replicates. The lower number of cows for BW reflected equipment failures during some periods and a failure of the scale readers to identify some cows.

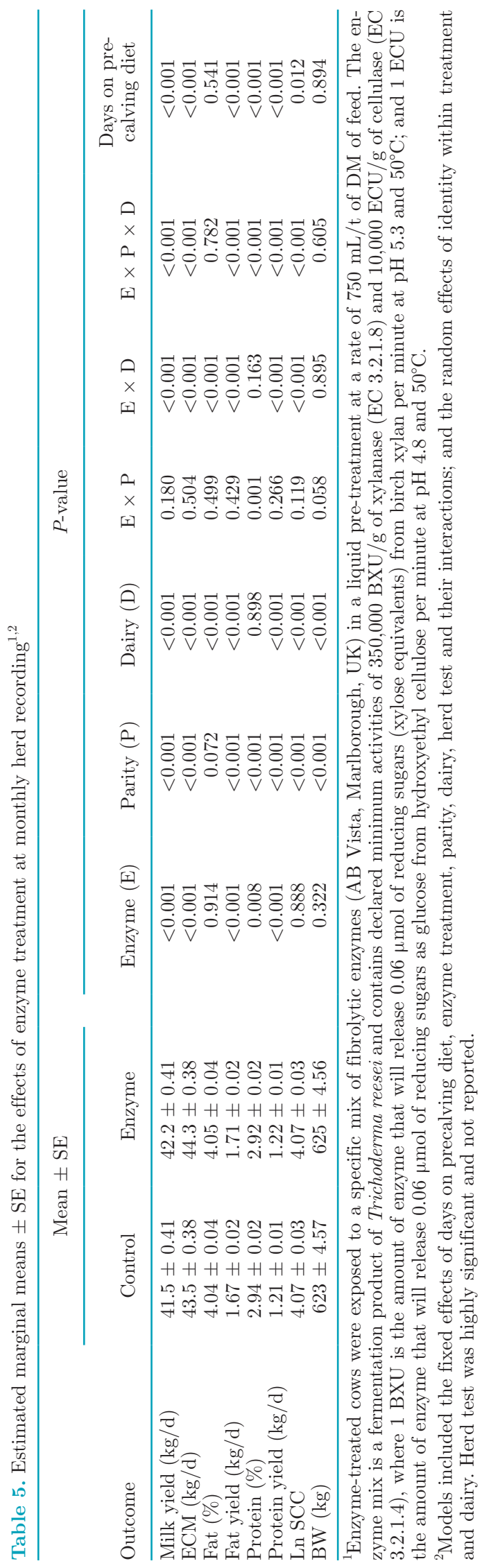

Journal of Dairy Science Vol. 102 No. 9, 2019 
Cows were fed the control or enzyme-treated diet for an average of $13.8 \pm 0.5,36.9 \pm 0.5$, and $12.6 \pm 0.1$ $\mathrm{d}$ before calving, at dairies 1,2 , and 3, respectively. Enzyme-treated cows were fed on average $2.4 \pm 0.2 \mathrm{~d}$ longer than controls; consequently, days on diet precalving was used as a covariate in analyses and was significant for all production measures except milk fat percentage and $\mathrm{BW}(P=0.541$ and 0.894 , respectively; Table 5).

Production and BW responses for enzyme-treated and control cows and $P$-values for effects of enzyme treatment and interactions are provided in Table 5 . Estimated marginal means for enzyme-treated and control cows by dairy are shown in Table 6. Figures $1 \mathrm{~A}$ to $\mathrm{H}$ show the marginal means and standard errors plotted over the 5 sampling months for each of the study variables. Milk production and ECM yield were increased by enzyme treatment across the 5-month test period $(P<0.001$; Table 5 ; Figures $1 \mathrm{~A}$ and $\mathrm{B}$, respectively). Milk fat percentage was not significantly affected by enzyme treatment (Figure 1C), but milk fat yield was significantly increased, by $0.040 \mathrm{~kg} / \mathrm{d}$ (Table 5 and Figure 1D). Although enzyme treatment reduced milk protein percentage by $0.020 \%$, milk protein yield was increased by $0.010 \mathrm{~kg} / \mathrm{d}$ (Table 5; Figure $1 \mathrm{~F}$ ). We found no evidence of an increase in the $\ln$ SCC for the enzyme-treated cows $(P=0.888$; Table 5 ; Figure $1 \mathrm{G})$. Overall, BW was numerically $2.0 \mathrm{~kg}$ higher for enzymetreated cows than for control cows $(P=0.322$; Table 5; Figure $1 \mathrm{H})$. The effect of parity was significant for all production responses except milk fat percentage $(P=$ 0.072); the effect of dairy was significant for all except milk protein percentage $(P=0.898)$.

The 3-way interaction between enzyme, parity, and dairy was significant for all production variables except milk fat percentage $(P=0.163)$ and $\mathrm{BW}(P=$
0.605). Enzyme by parity was significant only for milk protein percentage $(P<0.001)$. The enzyme $\times$ dairy interaction was significant for all production responses $(P<0.001)$ except protein percentage $(P=0.163)$ and BW $(P=0.895)$. For example, compared with controls, milk yield in enzyme-treated cows was significantly higher by $3.6 \mathrm{~kg} / \mathrm{d}$ at dairy 2 and numerically higher by 0.60 and $0.20 \mathrm{~kg} / \mathrm{d}$ at dairies 1 and 3 , respectively (Table 6). Dairy 2 had greater responses to treatment than dairies 1 and 3, especially in ECM, milk fat, and protein production (Table 6).

\section{DMI}

There was a total of 564 weekly observations of DMI across 16 pens. The numerical difference in DMI was $0.20 \mathrm{~kg} /$ head per day greater intake for the enzymetreated group $(P=0.160)$. Dry matter intake for the control and enzyme-treated pens over the 31 wk of the study are shown in Figure 2.

\section{Reproduction and Removal}

Figures $3 \mathrm{~A}$ and $\mathrm{B}$ show the cumulative breeding and pregnancy results, respectively, for the 7,500 cows analyzed for breeding or pregnancy using Kaplan-Meier estimates. Figure 3A shows very similar performance for the enzyme-treated and control cows for time to first breeding; however, enzyme-treated cows had a significantly greater probability of being bred per day than the control cows [hazard ratio $(\mathbf{H R})=1.266 ; P=$ 0.001]. However, this effect was influenced by days on the precalving $\operatorname{diet}(\mathrm{HR}=0.991 ; P=0.001)$, dairy $(P$ $<0.001)$, parity $(P<0.013)$, treatment $\times$ dairy $(P<$ $0.001)$, treatment $\times$ parity $(P<0.001)$, and treatment $\times$ dairy $\times$ parity $(P<0.001)$. Cows in parity 1 had

Table 6. Estimated marginal means \pm SE from monthly herd recording data for the effects of enzyme treatment ${ }^{1}$ by dairy

\begin{tabular}{|c|c|c|c|c|c|c|}
\hline Outcome & \multicolumn{2}{|c|}{ Dairy 1} & \multicolumn{2}{|c|}{ Dairy 2} & \multicolumn{2}{|c|}{ Dairy 3} \\
\hline Milk yield (kg/d) & $37.6 \pm 0.84$ & $38.2 \pm 0.84$ & $37.9 \pm 0.82$ & $41.5 \pm 0.82$ & $43.5 \pm 0.57$ & $43.7 \pm 0.57$ \\
\hline Fat $(\%)$ & $4.56 \pm 0.07$ & $4.46 \pm 0.07$ & $3.80 \pm 0.07$ & $3.86 \pm 0.07$ & $4.03 \pm 0.05$ & $4.02 \pm 0.05$ \\
\hline Fat yield $(\mathrm{kg} / \mathrm{d})$ & $1.73 \pm 0.04$ & $1.68 \pm 0.04$ & $1.35 \pm 0.04$ & $1.54 \pm 0.04$ & $1.77 \pm 0.03$ & $1.78 \pm 0.03$ \\
\hline Protein $(\%)$ & $2.91 \pm 0.03$ & $2.92 \pm 0.03$ & $2.94 \pm 0.03$ & $2.91 \pm 0.03$ & $2.95 \pm 0.01$ & $2.92 \pm 0.01$ \\
\hline
\end{tabular}

${ }^{1}$ Enzyme-treated cows were exposed to a specific mix of fibrolytic enzymes (AB Vista, Marlborough, UK) in a liquid pre-treatment at a rate of $750 \mathrm{~mL} / \mathrm{t}$ of $\mathrm{DM}$ of feed. The enzyme mix is a fermentation product of Trichoderma reesei and contains declared minimum activities of 350,000 $\mathrm{BXU} / \mathrm{g}$ of xylanase (EC 3.2.1.8) and 10,000 ECU/g of cellulase (EC 3.2.1.4), where $1 \mathrm{BXU}$ is the amount of enzyme that will release $0.06 \mu$ mol of reducing sugars (xylose equivalents) from birch xylan per minute at $\mathrm{pH} 5.3$ and $50^{\circ} \mathrm{C}$; and 1 ECU is the amount of enzyme that will release $0.06 \mu \mathrm{mol}$ of reducing sugars as glucose from hydroxyethyl cellulose per minute at $\mathrm{pH} 4.8$ and $50^{\circ} \mathrm{C}$. 

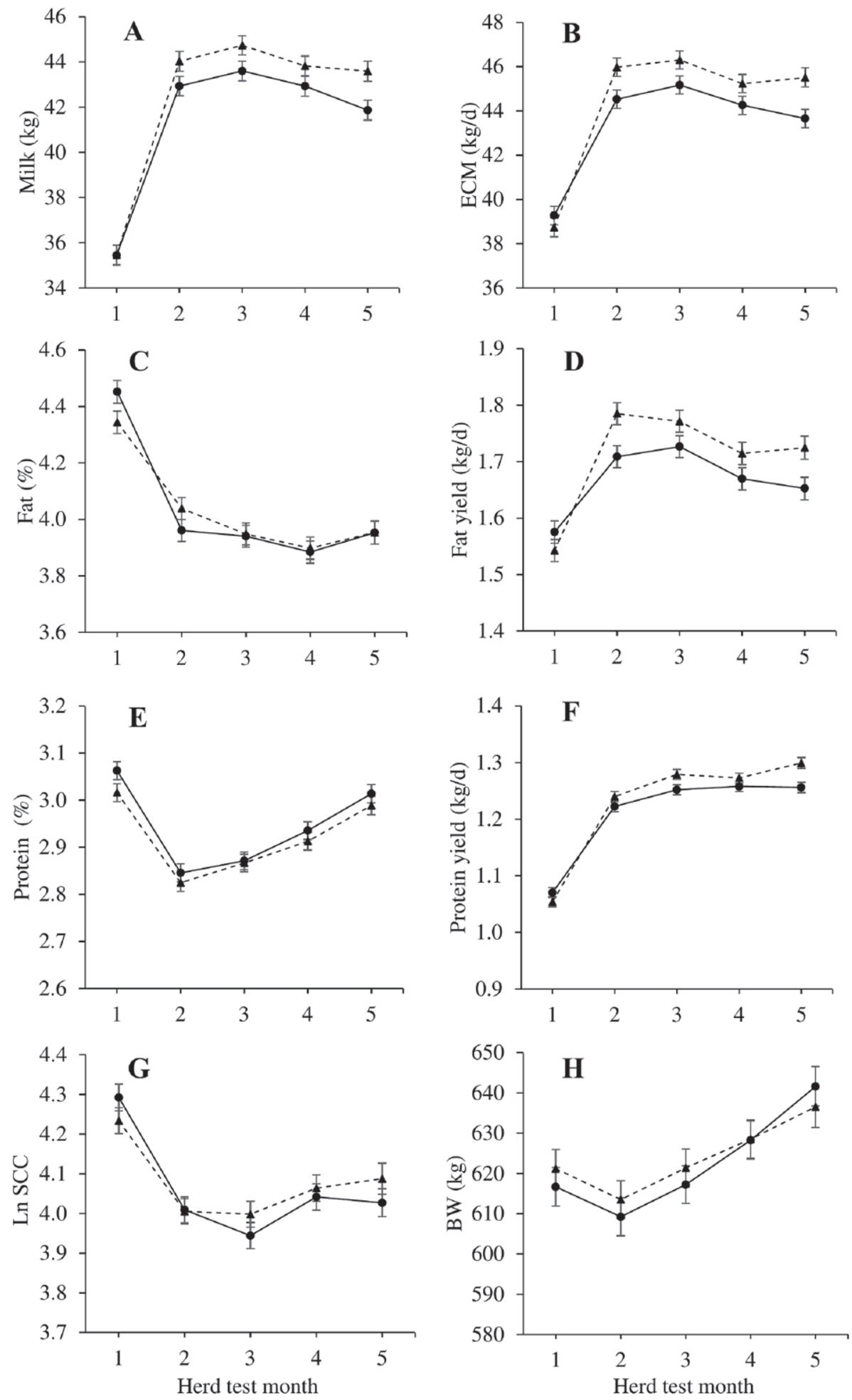

Figure 1. Mean monthly performance \pm SEM over 5 herd tests. (A) milk yield, (B) ECM, (C) fat percentage, (D) fat yield, (E) protein percentage, (F) protein yield, (G) ln SCC, and (H) BW for control $(\bullet)$ and enzyme-treated (ム) cows. Herd tests were conducted approximately every $30 \mathrm{~d}$. Herd test results collected from cows between 0 and 29 DIM were used as herd test 1, subsequent test results at 30-d intervals were used for tests 2 to 5. Enzyme-treated cows were exposed to a specific mix of fibrolytic enzymes (AB Vista, Marlborough, UK), in a liquid pretreatment at a rate of $750 \mathrm{~mL} / \mathrm{t}$ of $\mathrm{DM}$ of feed. The enzyme mix is a fermentation product of Trichoderma reesei and contains declared minimum activities of 350,000 BXU/g of xylanase (EC 3.2.1.8) and 10,000 ECU/g of cellulase (EC 3.2.1.4), where 1 BXU is the amount of enzyme that will release $0.06 \mu \mathrm{mol}$ of reducing sugars (xylose equivalents) from birch xylan per minute at $\mathrm{pH} 5.3$ and $50^{\circ} \mathrm{C}$; and 1 ECU is the amount of enzyme that will release $0.06 \mu \mathrm{mol}$ of reducing sugars as glucose from hydroxyethyl cellulose per minute at $\mathrm{pH} 4.8$ and $50^{\circ} \mathrm{C}$. 


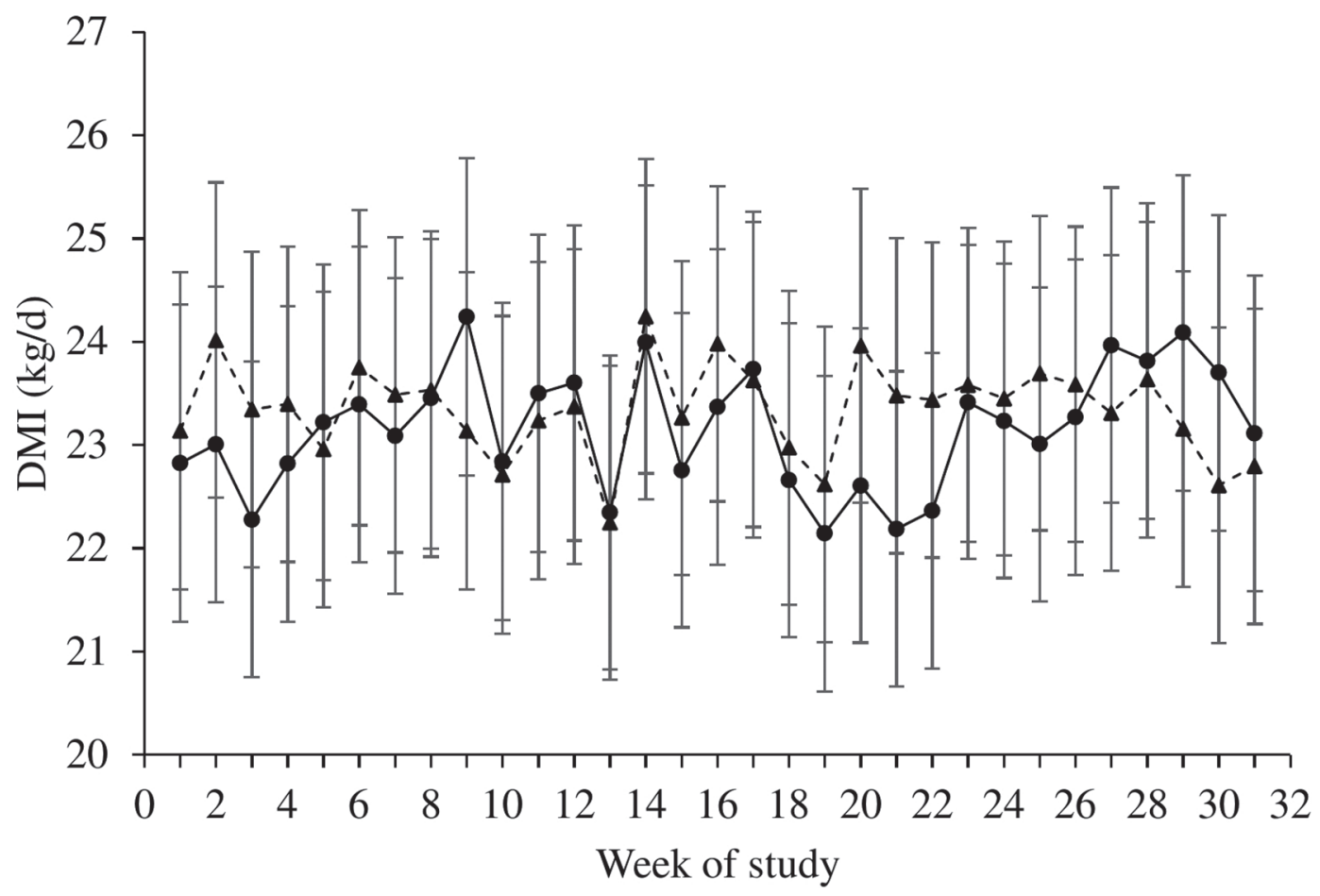

Figure 2. Mean DMI \pm SEM from 3 dairies for 8 replicated lactating pens of cows introduced to control $(\bullet)$ or enzyme-treatment $(\mathbf{\Delta})$ diets before calving by week of study. Enzyme-treated cows were exposed to a specific mix of fibrolytic enzymes (AB Vista, Marlborough, UK), in a liquid pre-treatment at a rate of $750 \mathrm{~mL} / \mathrm{t}$ of $\mathrm{DM}$ of feed. The enzyme mix is a fermentation product of Trichoderma reesei and contains declared minimum activities of 350,000 BXU/g of xylanase (EC 3.2.1.8) and 10,000 ECU/g of cellulase (EC 3.2.1.4), where 1 BXU is the amount of enzyme that will release $0.06 \mu \mathrm{mol}$ of reducing sugars (xylose equivalents) from birch xylan per minute at $\mathrm{pH} 5.3$ and $50^{\circ} \mathrm{C}$; and $1 \mathrm{ECU}$ is the amount of enzyme that will release $0.06 \mu \mathrm{mol}$ of reducing sugars as glucose from hydroxyethyl cellulose per minute at $\mathrm{pH} 4.8$ and $50^{\circ} \mathrm{C}$.

a lower probability of being bred than cows in parities 2,3 , and $\geq 4$. Compared with dairy 1 , cows from dairy 2 had a significantly greater probability being bred each day $(\mathrm{HR}=2.064 ; P=0.014)$ and cows from dairy 3 had a reduced probability $(\mathrm{HR}=0.609 ; P=$ 0.021). For time to pregnancy (Figure 3B), we found no significant increase in the probability of pregnancy over time $(\mathrm{HR}=0.966 ; P=0.949)$ for enzyme-treated cows. Days on the precalving diet was not significant $(\mathrm{HR}=0.997 ; P=0.066)$ and dairy $3 \mathrm{had}$ a significantly lower probability of cows becoming pregnant over time than the other 2 dairies. The interaction of dairy and parity and the 3-way interaction of dairy, parity, and treatment were not significant $(P>0.100)$.

The enzyme-treated cows were not at reduced risk of censoring for pregnancy $(\mathrm{HR}=0.907 ; P=0.734)$. The interactions of treatment with parity or dairy or their 3 -way interaction were not significant $(P>0.100)$. Cows in their fourth parity or more had a markedly greater risk of removal each day than parity 1 cows $(\mathrm{HR}=$ $2.21 ; P=0.005)$. We found no significant effect of days on the precalving diet (Figure $3 \mathrm{~B}$ ). The removals were not attributable to differences in deaths or culling $(P=$
0.088), as shown in Supplemental Figure S1 (https:// doi.org/10.3168/jds.2019-16601). Enzyme-treated cows were $6.2 \%$ more likely to stay in the herds over time.

\section{Health}

Health on the dairies was assessed using 7,507 cows. The diseases with highest incidence were mastitis, metritis, and lameness. Tables 7 and 8 show the proportion of cows with the different disorders. The only health measure that tended to differ with enzyme treatment was retained placenta, where the odds tended $(P=$ $0.080)$ to be $27 \%$ higher in enzyme-treated cows. We found notable differences in the risk or odds of disease for the different parity groups (Tables 7 and 8 ). Results for the survival analysis models for mastitis and lameness are shown in Table 8. For mastitis, we found a significant $(P=0.040)$ interaction among treatment, parity, and dairy, but none of dairy $\times$ treatment $(P=$ $0.438)$, treatment $\times$ parity $(P=0.837)$, or the effect of treatment $(\mathrm{HR}=1.04 ; P=0.589)$ were significant in the survival analysis. Lameness was not significantly increased by treatment $(\mathrm{HR}=1.05 ; P=0.875)$. The 

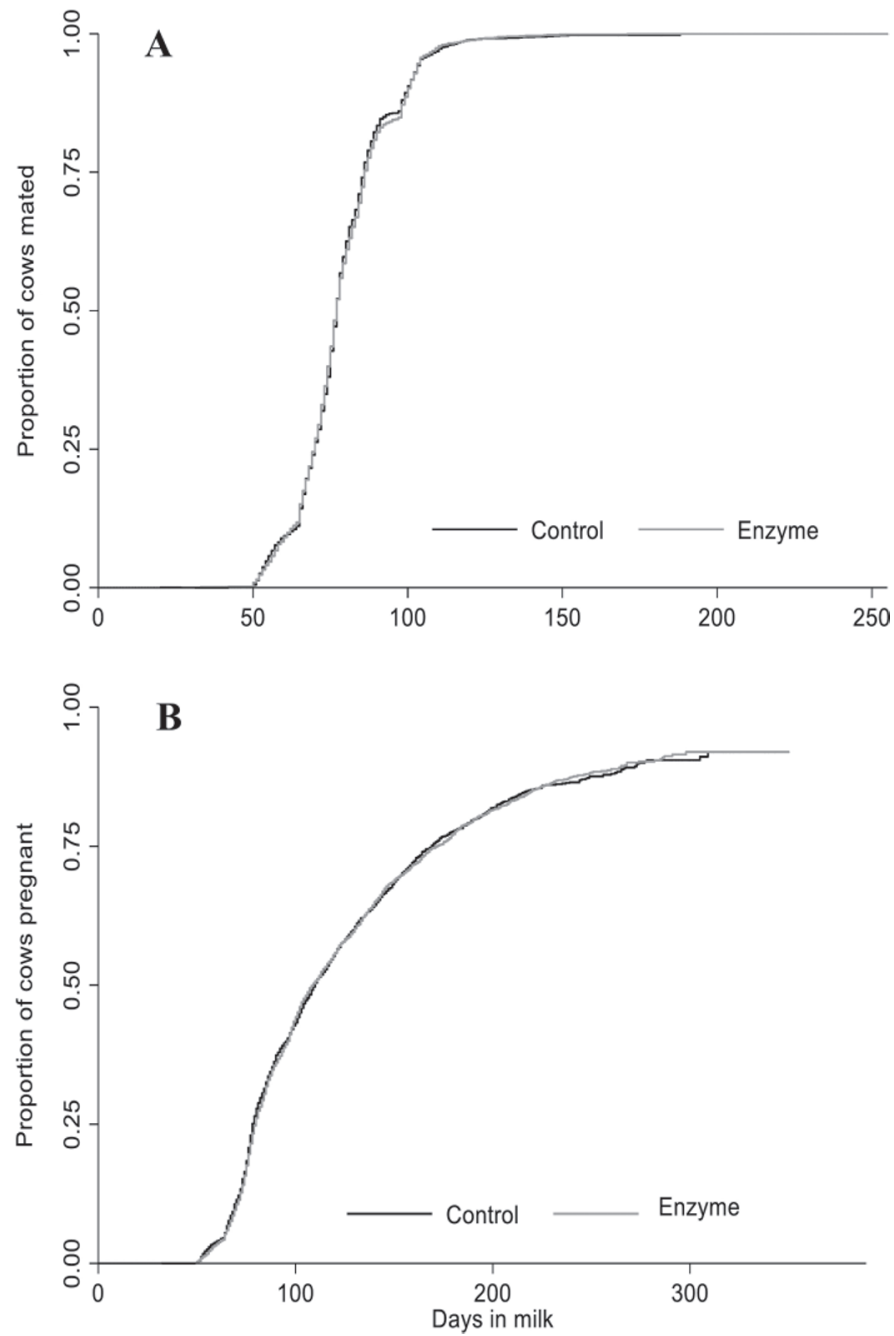

Figure 3. Cumulative proportion of cows in the control and enzyme groups (A) bred by DIM for cows that were bred, and (B) pregnant by DIM for cows that were pregnant. Enzyme-treated cows were exposed to a specific mix of fibrolytic enzymes (AB Vista, Marlborough, UK), in a liquid pre-treatment at a rate of $750 \mathrm{~mL} / \mathrm{t}$ of $\mathrm{DM}$ of feed. The enzyme mix is a fermentation product of Trichoderma reesei and contains declared minimum activities of $350,000 \mathrm{BXU} / \mathrm{g}$ of xylanase (EC 3.2.1.8) and 10,000 ECU/g of cellulase (EC 3.2.1.4), where $1 \mathrm{BXU}$ is the amount of enzyme that will release $0.06 \mu \mathrm{mol}$ of reducing sugars (xylose equivalents) from birch xylan per minute at $\mathrm{pH} 5.3$ and $50^{\circ} \mathrm{C}$; and $1 \mathrm{ECU}$ is the amount of enzyme that will release $0.06 \mu \mathrm{mol}$ of reducing sugars as glucose from hydroxyethyl cellulose per minute at $\mathrm{pH} 4.8$ and $50^{\circ} \mathrm{C}$.

probability of lameness was higher for higher-parity cows than for parity 1 cows, and differed by dairy, but interactions between treatment and parity or dairy were not significant.

\section{DISCUSSION}

This work details the responses of cows to an enzyme intervention when the enzyme was introduced to the

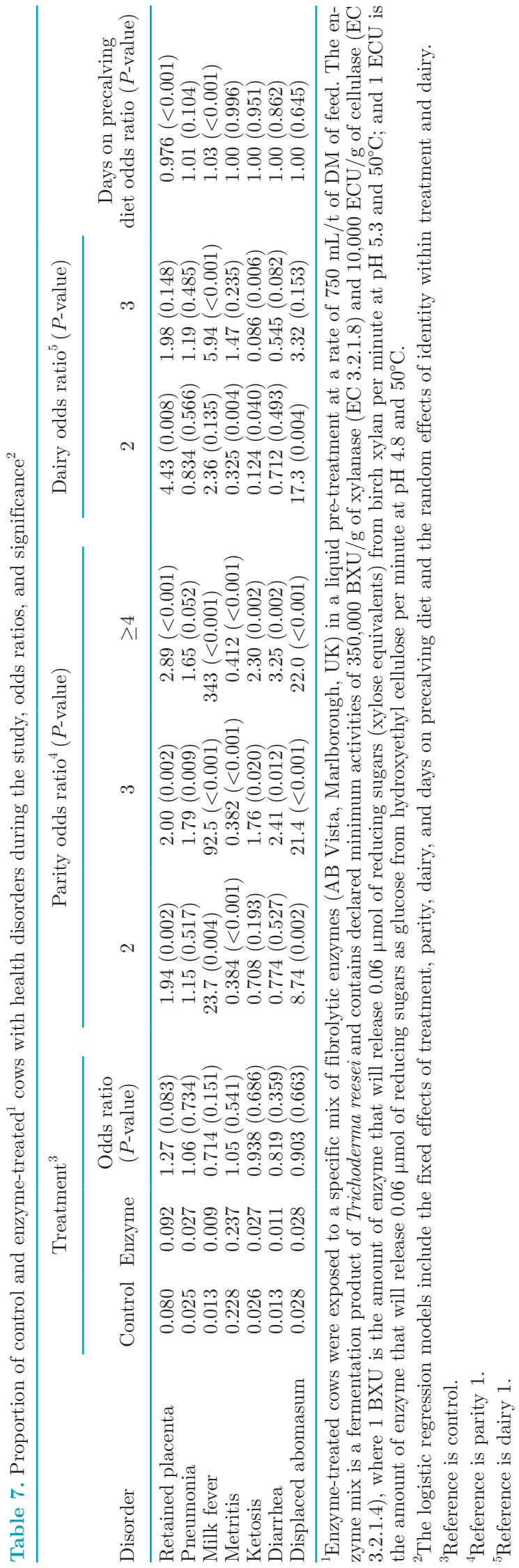

Journal of Dairy Science Vol. 102 No. 9, 2019 


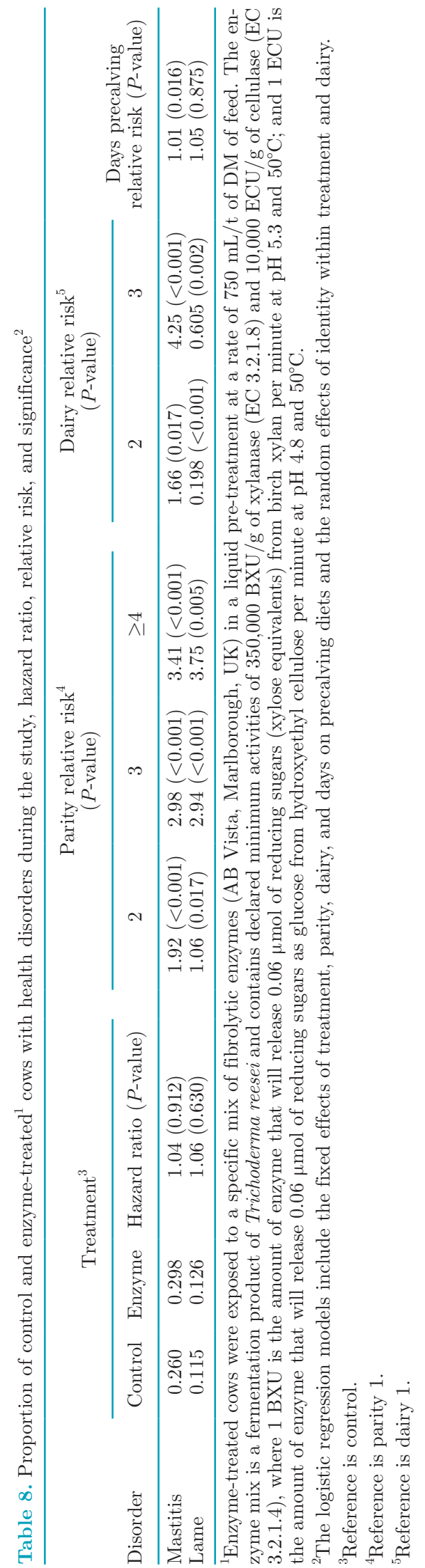

diet before calving. The results reflect the responses of a large study involving 3 dairies, 8 replicates, and 7,507 cows. The study design was adapted from those suggested by St-Pierre (2007), because of the strong external study validity achieved by exploring use of the enzyme intervention in the field and the potential to explore any variability in responses by careful monitoring of changes in the diet likely in commercial dairies. Further, this type of study provided opportunities to evaluate the effects of the treatment on reproductive performance and health. Compliance with the protocols for enzyme application was good for the dairies, as indicated by documented use of the enzyme and detection of the xylanase and cellulase activity in feed samples from treated pens. However, despite evidence of enzyme application, optimal xylanase and cellulase activity was not always detected, likely reflecting onfarm mixing failure.

The milk production responses for this study were similar to the results of previous meta-analyses (Arriola et al., 2017; Tirado-Gonazález et al., 2018) showing increased milk production responses to the introduction of an enzyme treatment. Arriola et al. (2017) found that the application of exogenous fibrolytic enzymes increased milk yield by $0.83 \mathrm{~kg} / \mathrm{d}$ and milk protein by $0.03 \mathrm{~kg} / \mathrm{d}$, and found a moderate $\left(I^{2}=40 \%\right)$ level of heterogeneity in milk production responses. This variability was evident in studies that evaluated production responses to the enzyme intervention (Beauchemin et al., 1999; Rode et al., 1999; Yang et al., 1999, 2000), with milk production responses in early-lactation cows of $0.9,3.6,1.6$, and $2.1 \mathrm{~kg} / \mathrm{d}$, respectively,. The cows in our study introduced to enzyme precalving in the transition period responded with increased milk $(0.70$ $\mathrm{kg} / \mathrm{d})$, ECM $(0.80 \mathrm{~kg} / \mathrm{d})$, milk fat, and milk protein yield. Cows' DMI was not influenced by treatment, and the numeric increase of $0.20 \mathrm{~kg} / \mathrm{d}$, measured on a pen basis, did not account for the increase in milk energy production. Cows' BW was numerically $2.0 \mathrm{~kg}$ higher for enzyme-treated cows, suggesting that use of the enzyme increased the DM digestibility of the feed. An increase in digestibility of feed is consistent with the increase in digestibility of NDF identified by Arriola et al. (2017). We found marked differences in milk production responses to the enzyme treatment by dairy; the possible reasons for this are explored in detail in a companion paper by $\mathrm{H}$. A. Rossow, H. M. Golder, and I. J. Lean, (unpublished). However, it is evident that diets differed markedly among dairies and this variation, along with the variation in application of the enzyme and environment influenced the responses. Tirado-González et al. (2018) suggests that exogenous fibrolytic enzymes may produce greater production responses when applied to diets that are 
higher in forage. In this study, dairy 3 had the lowest NDF concentration in the diet and the lowest response to treatment. Dairy 2, which was the most responsive, had higher concentrations of CP and NDF than dairy 3. Dairy 1 had the highest NDF concentration and a much higher forage-to-concentrate ratio than the other 2 dairies, which provided only about $30 \%$ of the diet as forage. Dairy 3 also had the lowest $\mathrm{Ca}, \mathrm{Mg}$, and DCAD of the dairies. Further, cows from dairy 3 were also the highest producing, suggesting that their production environment, including nutrition or genetics, was superior to the other dairies. It may be possible that responses to the enzyme did not provide additional nutrients required for increased production at that dairy, or that changes in rumen function resulting from treatment were not favorable; increased fiber digestibility in a herd with low NDF concentration could result in uncoupled fermentation and energy spilling (Strobel and Russell, 1986; Russell, 2007).

The effects of enzyme treatment on reproductive performance and health have not been explored in studies with sufficient power to evaluate these rigorously. We found no difference in time to pregnancy, but time to first breeding was significantly shorter for enzymetreated cows. However, the latter effect was influenced by significant interactions of treatment with parity and dairy and resulted in very similar performance overall. Although enzyme treatment provided more nutrients for production as evidenced by increased milk and milk solids production, it did not substantially influence reproductive performance. This outcome is similar to that of monensin interventions, which did not alter reproductive performance when the trials of this intervention were evaluated in a meta-analysis (Duffield et al., 2008).

We found no difference in patterns of survival: enzyme-treated cows were more likely to stay in the study, but had a nonsignificantly greater risk of culling and death. The findings in regard to survival are reflected in the health performance of the cows. We found no increase in the probability of mastitis over time, which was $4.0 \%$ higher in enzyme-treated cows. The odds of retained placenta tended to be higher $(27 \%)$ in the enzyme-treated group, but otherwise disease rates were similar between treatment groups. The effects of parity on risk of disease are of interest, because older cows, particularly those in the immediate periparturient period, are at much higher risk of disease.

\section{CONCLUSIONS}

The introduction of enzyme treatment to pens of cows in transition and enzyme treatment during the lacta- tion period increased yields of milk, fat, and protein, and reduced time to first breeding, but did not alter time to pregnancy. We found no differences for survival, disease, or ln SCC. Milk yield, ECM, and milk protein and fat production were increased, but the numeric increase in DMI was not sufficient to explain the increase in milk production. This observation combined, with a numeric increase in BW, suggests that treatment increased feed digestibility. There were differences in response to the enzyme treatment among dairies; the sources of variability in response to exogenous fibrolytic enzymes require further evaluation.

\section{ACKNOWLEDGMENTS}

The assistance of the dairy owners and managers was paramount to the conduct of the study. The contributions of Nicola Walker (AB Vista) and Ousama Alzahal (AB Vista) in study support are appreciated, along with financial support from AB Vista. Study monitors Mike Bettle (BritAm Nutritional Concepts Inc., Sioux Falls, SD) and Rod Riewer (Feedworks USA Ltd., Hutchinson, MN) assisted greatly in ensuring study compliance, as did a large number of students from the Veterinary Medical Teaching and Research Center (Tulare, CA, University of California, Davis). Finally, the input of Peter Williams (Advantec Associates Inc, Davis, CA, and Feedworks USA Ltd., Davis, CA) and Randy Cawood (AB Vista) on aspects of the diets was helpful and appreciated.

\section{REFERENCES}

Adesogan, A. 2005. Improving forage quality and animal performance with fibrolytic enzymes. Pages 91-109 in Proc. Florida Ruminant Nutrition Symposium, Gainesville, FL. University of Florida, Gainesville, FL.

AOAC International. 1999. Official Methods of Analysis. 16th ed. AOAC International, Washington, DC.

Arriola, K. G., A. S. Oliveira, Z. X. Ma, I. J. Lean, M. C. Giurcanu, and A. T. Adesogan. 2017. A meta-analysis on the effect of dietary application of exogenous fibrolytic enzymes on the performance of dairy cows. J. Dairy Sci. 100:4513-4527.

Beauchemin, K. A., D. Colombatto, and D. P. Morgavi. 2004. A rationale for the development of feed enzyme products for ruminants. Can. J. Anim. Sci. 84:23-36.

Beauchemin, K. A., W. Z. Yang, and L. M. Rode. 1999. Effects of grain source and enzyme additive on site and extent of nutrient digestion in dairy cows. J. Dairy Sci. 82:378-390.

Duffield, T. F., A. R. Rabiee, and I. J. Lean. 2008. A meta-analysis of the impact of monensin in lactating dairy cattle. Part 3. Health and reproduction. J. Dairy Sci. 91:2328-2341.

Hall, M. B., W. H. Hoover, J. P. Jennings, and T. K. M. Webster. 1999. A method for partitioning neutral detergent-soluble carbohydrates. J. Sci. Food Agric. 79:2079-2086.

Krishnamoorthy, U., T. Muscato, C. Sniffen, and P. Van Soest. 1982. Nitrogen fractions in selected feedstuffs. J. Dairy Sci. 65:217-225.

NRC (National Research Council). 1988. Nutrient Requirements of Dairy Cattle. 6th ed. Natl. Acad. Press, Washington, DC. 
NRC (National Research Council). 2001. Nutrient Requirements of Dairy Cattle. 7th ed. Natl. Acad. Press, Washington, DC.

Rode, L. M., W. Z. Yang, and K. A. Beauchemin. 1999. Fibrolytic enzyme supplements for dairy cows in early lactation. J. Dairy Sci. $82: 2121-2126$

Russell, J. B. 2007. The energy spilling reactions of bacteria and other organisms. J. Mol. Microbiol. Biotechnol. 13:1-11.

St-Pierre, N. R. 2007. Design and analysis of pen studies in the animal sciences. J. Dairy Sci. 90:E87-E99.

Strobel, H. J., and J. B. Russell. 1986. Effect of $\mathrm{pH}$ and energy spilling on bacterial protein synthesis by carbohydrate-limited cultures of mixed rumen bacteria. J. Dairy Sci. 69:2941-2947.

Tirado-González, D. N., L. A. Miranda-Romero, A. Ruíz-Flores, S. E. Medina-Cuéllar, R. Ramírez-Valverde, and G. Tirado-Estrada. 2018. Meta-analysis: Effects of exogenous fibrolytic enzymes in ruminant diets. J. Appl. Anim. Res. 46:771-783.
Van der Honing, Y., and A. Steg. 1990. Comparison of energy evaluation systems of feeds for ruminants. Page 6 in Feedstuff Evaluation. J. Wiseman and D. J. A. Cole, ed. Butterworths, London, UK.

Van Soest, P. J., J. B. Robertson, and B. A. Lewis. 1991. Methods for dietary fiber, neutral detergent fiber, and nonstarch polysaccharides in relation to animal nutrition. J. Dairy Sci. 74:3583-3597.

Weiss, W. 1993. Predicting energy values of feeds. J. Dairy Sci. 76:1802-1811

Yang, W. Z., K. A. Beauchemin, and L. M. Rode. 1999. Effects of an enzyme feed additive on extent of digestion and milk production of lactating dairy cows. J. Dairy Sci. 82:391-403.

Yang, W. Z., K. A. Beauchemin, and L. M. Rode. 2000. A comparison of methods of adding fibrolytic enzymes to lactating cow diets. J. Dairy Sci. 83:2512-2520. 